\title{
THE ANNUAL MEETING OF THE SOCIETY
}

The forty-fifth Annual Meeting of the American Mathematical Society was held at Richmond and Williamsburg, Virginia, from Tuesday to Friday, December 27-30, 1938, in conjunction with the meetings of the American Association for the Advancement of Science and the Mathematical Association of America.

There were three general and seven sectional sessions of the Society, in which four addresses and ninety-five research papers (fiftyfour in person) were given. Sessions on Wednesday morning were held in the Broadcasting Studio of the Mosque, Richmond. All other sessions were held in Washington Hall and Rogers Hall at the College of William and Mary, Williamsburg.

Arrangements for the meetings were made by a committee consisting of Professors J. M. Stetson (chairman), E. J. McShane, G. A. Larew, and C. H. Wheeler. In Richmond the headquarters were at the Hotel William Byrd. In Williamsburg, the College of William and Mary generously made dormitory rooms available for the use of the mathematicians.

The attendance of approximately three hundred included the following two hundred thirty members of the Society:

C. R. Adams, R. B. Adams, V. W. Adkisson, R. P. Agnew, C. B. Allendoerfer, R. C. Archibald, C. S. Atchison, N. H. Ball, M. F. Becker, A. A. Bennett, G. D. Birkhoff, L. M. Blumenthal, Paul Boeder, H. F. Bohnenblust, H. E. Bray, W. C. Brenke, J. L. Brenner, F. L. Brooks, E. T. Browne, Herbert Busemann, J. H. Bushey, Jewell H. Bushey, W. E. Byrne, W. D. Cairns, J. W. Calkin, H. H. Campaigne, E. W. Cannon, M. E. Carlen, C. L. Carroll, I. S. Carroll, H. C. Carter, W. B. Carver, J. W. Cell, Claude Chevalley, Alonzo Church, J. M. Clarkson, Abraham Cohen, L. W. Cohen, Nancy Cole, J. B. Coleman, J. L. Coolidge, W. A. Cordrey, Richard Courant, E. B. Cowley, Sr. J. S. Creane, H. B. Curry, D. R. Curtiss, E. H. Cutler, M. D. Darkow, H. T. Davis, F. F. Decker, L. L. Dines, Arnold Dresden, F. G. Dressel, R. J. Duffin, W. L. Duren, L. A. Dye, Paul Erdös, W. H. Erskine, E. J. Finan, D. A. Flanders, L. R. Ford, Tomlinson Fort, R. H. Fox, J. S. Frame, K. O. Friedrichs, T. C. Fry, R. E. Gaines, J. J. Gergen, F. J. Gerst, Wallace Givens, Kurt Gödel, M. C. Graustein, W. C. Graustein, C. H. Graves, D. W. Hall, Israel Halperin, Harris Hancock, M. L. Hartung, N. A. Haynes, O. C. Hazlett, L. B. Hedge, E. R. Hedrick, E. H. C. Hildebrandt, Einar Hille, D. L. Holl, T. R. Hollcroft, M. A. Holly, Charles Hopkins, V. A. Hoyle, W. A. Hurwitz, Dunham Jackson, Nathan Jacobson, C. G. Jaeger, Walter Jennings, Fritz John, F. E. Johnston, B. W. Jones, F. B. Jones, H. A. Jordan, J. L. Kelley, A. J. Kempner, S. C. Kleene, J. R. Kline, R. L. Korgen, H. L. Krall, W. D. Lambert, F. L. Lamoreau, O. E. Lancaster, Lincoln LaPaz, G. A. Larew, C. G. Latimer, V. S. Lawrence, B. A. Lengyel, D. C. Lewis, J. B. Linker, S. B. Littauer, M. I. Logsdon, R. G. Lubben, N. H. McCoy, E. A. McDougle, E. J. McShane, C. C. MacDuffee, Saunders MacLane, H. M. MacNeille, H. F. MacNeish, Dorothy Manning, W. A. Manning, A. J. Maria, William Marshall, M. H. Martin, 
A. K. Mitchell, Virginia Modesitt, E. C. Molina, C. N. Moore, R. L. Moore, T. W. Moore, E. M. Morenus, W. K. Morrill, E. J. Moulton, C. G. Mumford, F. L. Munroe, C. W. Munshower, F. D. Murnaghan, S. B. Myers, John von Neumann, C. O. Oakley, G. A. O'Donnell, F. W. Owens, H. B. Owens, J. C. Oxtoby, E. K. Paxton, A. M. Pegram, E. W. Pehrson, H. A. Perkins, B. J. Pettis, C. S. Pettis, Everett Pitcher, M. H. Plass, G. B. Price, W. T. Puckett, H. A. Rademacher, J. F. Randolph, Herbert ReBarker, M. S. Rees, W. D. Reeve, R. G. D. Richardson, R. F. Rinehart, E. K. Ritter, H. E. Robbins, J. H. Roberts, H. A. Robinson, Barkley Rosser, H. G. Russell, S. T. Sanders, O. F. G. Schilling, I. J. Schoenberg, G. E. Schweigert, W. T. Scott, Wladimir Seidel, C. G. Shover, R. G. Simond, Abraham Sinkov, F. C. Smith, J. P. Smith, R. G. Smith, W. F. Smith, Virgil Snyder, F. W. Sohon, C. A. Spicer, M. E. Stark, N. E. Steenrod, J. M. Stetson, C. N. Stokes, M. H. Stone, R. R. Struik, Alvin Sugar, Otto Szász, J. D. Tamarkin, J. H. Taylor, M. E. Taylor, J. M. Thomas, E. W. Titt, C. B. Tompkins, C. C. Torrance, E. M. Torrance, W. J. Trjitzinsky, B. M. Turner, S. M. Ulam, A. D. Wallace, S. E. Warschawski, J. H. Weaver, Warren Weaver, J. V. Wehausen, M. J. Weiss, M. E. Wells, V. H. Wells, A. P. Wheeler, C. H. Wheeler, G. T. Whyburn, D. V. Widder, Norbert Wiener, C. W. Williams, K. P. Williams, E. W. Wilson, H. A. Wood, F. L. Wren, B. F. Yanney, M. M. Young, H. S. Zuckerman.

On Tuesday evening, Dean G. D. Birkhoff delivered an address as retiring President of the A.A.A.S. on the subject Intuition, reason and faith in science. The address was followed by a reception, for all members of the Association and affiliated societies, at the Hotel Jefferson.

On Wednesday morning, at 9:30 A.M., at a joint session of the Society, the Mathematical Association of America, and Sections A and $E$ of the A.A.A.S., Professor W. D. Cairns gave an address as retiring Vice President of the A.A.A.S. and Chairman of Section A. The subject was Seismology from a mathematical viewpoint. Professor J. R. Kline, Chairman of Section A, presided at this session.

On Wednesday morning, at 10:45 A.M., at a joint session of the Society, the Mathematical Association of America, and Sections A and $L$ of the A.A.A.S., Professor R. C. Archibald gave an address as retiring Vice President of the A.A.A.S. and Chairman of Section L. His subject was Mathematicians, and poetry and drama. Professor D. R. Curtiss presided.

Wednesday afternoon there were two sectional sessions of the Society, one for Analysis and one for Topology and Geometry. Professors M. H. Stone and G. T. Whyburn presided. Thursday morning there were three sessions, for Analysis, Calculus of Variations and Applied Mathematics, and Algebra, at which Professor J. J. Gergen, Dr. Warren Weaver, and Professor N. H. McCoy presided. There were also two sessions on Friday morning, one for Analysis and one for Topology, at which Professors H. E. Bray and R. L. Moore presided. 
The general session Thursday afternoon began with the business meeting and annual election. Following this, Professor R. L. Moore gave his address as the retiring President of the Society. His subject was $O n$ certain abstract spaces. Professor H. A. Rademacher then gave an address, by invitation of the Program Committee, on Fourier expansions of modular functions and theorems on partitions. At the close of the general session, the Bôcher Memorial Prize was awarded to Professor John von Neumann, who gave a résumé of the paper for which the prize was awarded (Almost periodic functions and groups, Transactions of this Society, vol. 36 (1934), pp. 445-492). Vice President C. R. Adams presided at this session.

Sessions of the Mathematical Association of America were held on Friday afternoon and Saturday morning and of the National Council of Teachers of Mathematics, Friday morning and afternoon.

A joint dinner for members of the mathematical organizations and their guests was held on Thursday evening in the Dining Hall, College of William and Mary. The attendance was three hundred and seven. Professor F. D. Murnaghan was toastmaster. There were six speakers: President J. S. Bryan of the College of William and Mary, an address of welcome to Williamsburg; Professor G. T. Whyburn, representing mathematicians of the South; Professor J. L. Coolidge, on the history of mathematics in Virginia; Professor R. L. Moore, retiring President of the Society, representing the Society; Professor W. B. Carver, President-elect of the Association, representing the Association; Dean R. G. D. Richardson, Secretary of the Society, on the proposition of starting an abstract journal in America. Professor L. R. Ford presented resolutions, which were adopted unanimously, thanking the College of William and Mary, the local committee, and all those who assisted them for their excellent arrangements and cordial hospitality.

There were excursions to historic places in Richmond Tuesday afternoon and Wednesday morning, and also to Jamestown and Yorktown Thursday afternoon. Members and guests visited the Williamsburg Restoration Buildings at various times during the meeting.

At the meeting of the Board of Trustees at 6:30 P.M., Tuesday, December 27, in the Hotel William Byrd, there was not a quorum present. An adjourned meeting, therefore, was held on December 31, at 6:30 P.M., in the Men's Faculty Club of Columbia University, New York City.

The Council met on Thursday, December 29, at 12:00 M. in the Dining Hall of the College of William and Mary, and at 10:30 P.M. in Room 200 of Washington Hall. 
The Secretary announced the election of the following twenty-one persons to membership in the Society:

Professor Sam Kelley Bright, Blinn College, Brenham, Texas;

Mr. Richard Hubert Bruck, University of Toronto;

Professor Alexander V. Bushkovitch, College of Charleston, Charleston, S. C.;

Mr. John Chesna, Bausch and Lomb Optical Company, Rochester, N. Y.;

Mr. Wilfred Joseph Dixon, University of Wisconsin;

Professor William Cletus Doyle, Rockhurst College, Kansas City, Mo.;

Professor William Louis Fields, Agricultural, Mechanical, and Normal College, Pine Bluff, Ark.;

Sister M. Immaculata Garrahan, College Misericordia, Dallas, Pa.;

Mr. Robert Ewing Greenwood, Jr., University of Texas;

Dr. Olaf Helmer, University of Illinois;

Mr. Robert B. Kleinschmidt, Monmouth Junior College, Long Branch, N. J.;

Mr. Kenneth Floyd McLaughlin, Des Moines, Iowa;

Mr. Don Dalzell Miller, Ohio University;

Professor Jerzy Neyman, University of California;

Mr. Sidney Thomas Parker, Hobart College;

Professor Glenn Harold Peebles, University of Minnesota;

Mr. Clement Russell Phelps, Georgia School of Technology;

Mr. William Haddock Simons, University of California;

Professor John P. Smith, S.J., St. Peter's College, Jersey City, N. J.;

Professor Kadri Hafiz Tukan, Najah National College, Nablus, Palestine;

Dr. Henry Allen Wood, Connecticut State College.

It was reported that the following had been elected as nominees on the Institutional Memberships of the institutions indicated:

Acadia University: Dr. Moray St. John Macphail.

University of California at Los Angeles: Messrs. Paul Joseph Kelly and Burris Palmer Taylor.

University of Chicago: Messrs. Morris Bloom, Ralph Nathanael Johanson, Albert Neuhaus, and George W. Whitehead.

College of the City of New York: Mr. Herbert L. Mintzer.

Cornell University: Dr. Samuel Saslaw and Mr. Gordon Loftis Walker.

University of Illinois: Messrs. Paul Hamilton Anderson, Philip Wilkinson Carruth, Benjamin Epstein, James Francis Heyda, Franz Edward Hohn, Thomas Eddy Judd, Paul Edison Lewis, Kaj Leo Nielsen, Charles Frederick Strobel, and Chester William Topp.

Institute for Advanced Study: Dr. Valentin Bargmann, Professor Claude Chevalley (University of Rennes, Rennes, France), Dr. Paul Erdös, Dr. Herbert Ellis Robbins, and Mr. Jacobus Stephanus de Wet.

The State University of Iowa: Mr. John Wesley Kitchens.

The Johns Hopkins University: Mr. Abraham Seidenberg.

University of Kentucky: Mr. James Malcolm Boswell.

Massachusetts Institute of Technology: Messrs, Abe Gelbart, Abraham Schwartz, and Samuel Woodard Stewart.

University of Michigan: Dr. Preston Clarence Hammer, Messrs. Samuel Kaplan, Horace Komm, John William Odle, and Charles E. Rickart.

Michigan State College of Agriculture and Applied Science: Mr. John William Zimmer. 
Northwestern University: Mr. Paul B. Burcham, Miss Mary Margaret Handel, Messrs. Joseph Findlay Paydon and Richard Harlan Stark.

Syracuse University: Mr. John Emerson Hart.

University of Virginia: Mr. Richard Cyrus Morrow.

University of Washington: Messrs. Bradford Henry Arnold and George Arthur Whetstone.

Wayne University: Miss Margaret Jean Dunford.

Wesleyan University: Mr. James Henry Perryman.

The following appointments by President R. L. Moore were reported: as representative of the Society at the inauguration of Charles Burgess Ketcham as President of Mount Union College, Alliance, Ohio, on October 20, Professor B. F. Yanney; as representative of the Society at the inauguration of Karl Clayton Leebrick as President of Kent State University of Ohio, Kent, Ohio, on October 21, Dean W. G. Simon; as representative of the Society at the inauguration of Leonard Carmichael as President of Tufts College, Medford, Massachusetts, on November 4, Professor E. V. Huntington; as representative of the Society at the installation of Edwin Sharp Burdell as Director of The Cooper Union for the Advancement of Science and Art, New York, N. Y., on November 3, Professor W. B. Fite; as tellers for the election at the Annual Meeting, Professor C. H. Wheeler and Dr. E. R. Lorch; as auditors of the Society's books for the year 1938, Professors R. G. Archibald and A. E. Meder, Jr.; as a committee to nominate a representative on the National Research Council for a period of three years beginning July, 1939, and two representatives on the Council of the American Association for the Advancement of Science for the year 1939, Dean G. D. Birkhoff (chairman), Professor G. A. Bliss, and Dean L. P. Eisenhart; as committees to select hour speakers for various meetings: as the Committee for Annual and Summer Meetings, the Secretary (chairman), Professors A. B. Coble (one year) and J. R. Kline (two years); as the Committee for Eastern Sectional Meetings, the secretary for those meetings (chairman), Dean L. P. Eisenhart (two years), and Professor J. L. Walsh (one year); as the Committee for Western Sectional Meetings, the secretary for those meetings (chairman), Professors G. A. Bliss (two years) and T. H. Hildebrandt (one year): as the Committee for Far Western Sectional Meetings, the secretary for those meetings (chairman), Provost E. R. Hedrick (two years), and Professor G. C. Evans (one year).

The Secretary reported that the ordinary membership in the Society is now 2,200, including 151 nominees of institutional members and 78 life members. There are also 86 institutional members. The total attendance of members at all meetings in 1938 was 1,435 ; the 
number of papers read was 475 ; the number of invited addresses was 21 ; the number of members attending at least one meeting was 848 .

At the annual election which closed on December 29, and at which 373 votes were cast ( 349 for the list nominated by the Council), the following officers were elected:

President, Professor G. C. Evans.

Vice President, Professor C. R. Adams.

Associate Secretary, Professor T. R. Hollcroft.

Treasurer, Professor B. P. Gill.

Librarian, Professor R. C. Archibald.

Members of the Editorial Committee of the Bulletin, Professors A. A. Albert and Tomlinson Fort.

Member of the Editorial Committee of the Transactions, Professor W. C. Graustein.

Member of the Editorial Committee of the Colloquium Publications, Professor M. H. Stone.

Member of the Editorial Board of the American Journal, Professor R. L. Wilder.

Members of the Council, Professors H. E. Bray, Alonzo Church, E. J. McShane, H. P. Robertson, and Hermann Weyl.

Members of the Board of Trustees, Professor W. B. Fite, Dr. Robert Henderson, Professors W. R. Longley and G. W. Mullins, and Dean R. G. D. Richardson.

The reports of the Treasurer and auditors (Professors R. G. Archibald and A. E. Meder, Jr.) showed a balance of $\$ 12,635.94$ exclusive of the balances in the Colloquium, Sinking Fund, and special funds. The Society's investments including Endowment Fund, Sinking Fund, and other special funds had a market value on November 30, 1938 , of approximately $\$ 90,000$. The net interest income for the year was $\$ 3,762.48$; dues from Institutional Memberships amounted to $\$ 6,455$; dues from Contributing Memberships, $\$ 1,124.96$; and dues from Ordinary Memberships were $\$ 13,406.16$. The Colloquium Fund showed a balance of $\$ 10,813.91$. The total received from the sale of the Society's publications was $\$ 10,421.64$. The Board of Trustees adopted a budget for 1939 showing estimated expenditures and receipts of the Society (exclusive of Congress funds) as $\$ 36,250$ and $\$ 32,550$, respectively.

The Librarian reported that the Library of the Society now contains about 9,150 volumes.

Invitations were received for the Annual Meeting of 1940 from Louisiana State University, University of Pennsylvania, and Lehigh 
University. A committee was appointed to make recommendations regarding the choice of place.

An invitation was received from Northwestern University for the Society to meet at that institution in the summer of 1943 , this being the fiftieth anniversary of the first Colloquium of the Society, when Professor Felix Klein spoke at Evanston.

Times and places of meetings in 1939 were fixed as follows: Stanford University, April 15; Madison, September 5-8; New York City, October 28.

Dr. Thornton C. Fry, executive secretary of the Committee on the Semicentennial Celebration, made a final report. He stated that of the $\$ 5,500$ set aside for publication expenses, there remains a balance of $\$ 854.75$ and that from sales of publications the Society can expect to receive a considerable portion of the difference. The cost of the portrait and of testimonials to Professor T. S. Fiske was met by special subscriptions, accounted for outside of the funds of the Society. Of the $\$ 1,500$ set aside for other purposes of the Semicentennial, there remains a balance of $\$ 1,156.71$.

The Organizing Committee of the Congress reported on a variety of matters such as arrangements with the United States Government to send out invitations to foreign governments, plans for inviting delegates, a list of twenty-five persons to be invited to give hour addresses at the Congress, arrangements for notifying universities about possible foreign lecturers for the summer of 1940, and the amount of $\$ 27,500$ pledged for carrying on the work of the Congress.

A committee consisting of Professor C. R. Adams (chairman), Dean G. D. Birkhoff, Professor A. B. Coble, Dr. T. C. Fry, Professors Marston Morse and G. T. Whyburn was appointed to ascertain whether the time is favorable for starting an abstract journal in America under the auspices of the Society, whether international cooperation for such a venture can be obtained, and whether money is available from sources outside the Society for an initial period of five years. If studies show that conditions in these respects are favorable, the committee has power to proceed promptly to set up such a journal for an experimental five-year period.

A petition was received from a group of members of the Society, requesting changes in the by-law regarding election of members of the Council.

Professor Theodore von Kármán of the California Institute of Technology was invited to deliver the Josiah Willard Gibbs Lecture in December, 1939, in connection with the Annual Meeting.

The Cole Prize in Algebra is to be awarded at the Annual Meeting 
of 1939 to the author of a paper in Algebra published during the years 1934-1938.

Titles and cross references to the abstracts of papers read at the regular sessions follow below. The papers were read as follows: papers numbered 1 to 7 in the section for Analysis on Wednesday afternoon; papers 8 to 12 in the section for Topology and Geometry on Wednesday afternoon; papers 13 to 20 in the section for Analysis on Thursday morning; papers 21 to 28 in the section for Calculus of Variations and Applied Mathematics on Thursday morning; papers 29 to 37 in the section for Algebra on Thursday morning; papers 38 to 46 in the section for Analysis on Friday morning; papers 47 to 54 in the section for Topology on Friday morning; and papers 55 to 95, whose abstract numbers are followed by the letter $t$, were read by title. Of those presenting papers, Mr. C. J. Blackall was introduced by Dr. D. C. Lewis, Dr. Albert Heins by Mr. H. F. S. Jonah, Mr. M. H. Heins by Professor J. L. Walsh, and Mr. Venable Martin by Professor J. H. Roberts.

1. C. J. Blackall: Volume integral invariants of non-holonomic systems. (Abstract 45-1-3.)

2. F. C. Smith: Relations among the fundamental solutions of the generalized hypergeometric equation when $p=q+1$. II. Logarithmic cases. (Abstract 45-1-62.)

3. Fritz John: An identity for the integrals of a function over two concentric ellipsoids. (Abstract 45-1-27.)

4. R. H. Cameron and Norbert Wiener: Convergence properties of analytic functions of Fourier-Stieltjes transforms. (Abstract 45-1-8.)

5. C. O. Oakley: On the representation of line segments in the plane by equalities. (Abstract 45-1-48.)

6. Israel Halperin: The spectrum of a continuous flow. (Abstract 45-1-19.)

7. Kurt Gödel: The consistency of the generalized continuumhypothesis. (Abstract 45-1-108.)

8. G. E. Schweigert - Concerning the hyperspace associated with a pointwise periodic transformation. (Abstract 45-1-58.)

9. L. M. Blumenthal and G. R. Thurman: Spheroidal and pseudospheroidal spaces. (Abstract 45-1-4.)

10. L. A. Dye: Involutorial transformations determined by two systems of lines. (Abstract 45-1-12.)

11. G. B. Price: Spaces whose elements are sets. (Abstract 45-1-54.)

12. D. W. Hall (National Research Fellow): On pointwise periodic homeomorphisms in the plane. Preliminary report. (Abstract 45-1-87.)

13. O. E. Lancaster: Orthogonal polynomials defined by difference equations. (Abstract 45-1-32.) 
14. John von Neumann and I. J. Schoenberg: Fourier integrals and metric geometry. II. (Abstract 45-1-47.)

15. J. A. Shohat and J. D. Tamarkin: On mechanical quadrature formulas for infinite intervals. (Abstract 45-1-61.)

16. L. R. Ford: Normal families and differential equations. (Abstract 45-1-14.)

17. H. M. MacNeille: A constructive theory of integration. (Abstract 45-1-41.)

18. W. T. Scott and H. S. Wall: Properties of analytic functions derived from their corresponding continued fractions. (Abstract 45-1-59.)

19. Otto Szász: On the Cesàro and Riesz means of Fourier series. (Abstract 45-1-66.)

20. L. B. Hedge: Integration in a compact metric space. (Abstract 45-1-88.)

21. Everett Pitcher: The critical points of a map on a circle. (Abstract 45-1-53.)

22. K. O. Friedrichs and J. J. Stoker: The nonlinear boundary value problem of the buckled plate. (Abstract 45-1-15.)

23. E. J. McShane: The Jacobi condition and the index theorem in the calculus of variations. (Abstract 45-1-38.)

24. M. H. Martin: Restricted problems in three bodies. Preliminary report. (Abstract 45-1-43.)

25. F. L. Lamoreau: Temperature distribution in a long rectangular bar of two layers. (Abstract 44-9-393.)

26. Ruth R. Struik and Miriam van Waters: $A$ mathematical method applied to criminology. (Abstract 45-1-64.)

27. Alfred Korzybski: Extensionalization in mathematics, mathematical physics, and general education. General semantics. II. (Abstract 45-1-31.)

28. Harald Bohr and D. A. Flanders: Algebraic functions of analytic almost periodic functions. (Abstract 45-1-79.)

29. O. F. G. Schilling: A remark on normal extensions. (Abstract 44-11-473.)

30. Charles Hopkins: Rings with minimal condition for left ideals. (Abstract 45-1-25.)

31. B. W. Jones: A note on a minimum for positive quadratic forms. (Abstract 45-1-28.)

32. Saunders MacLane: Modular fields. I. Separating transcendence bases. (Abstract 45-1-39.)

33. W. A. Manning: A note on transitive groups with regular subgroups of the same degree. (Abstract 45-1-42.) 
34. A. J. Kempner: On the roots of algebraic equations with complex coeffcients. (Abstract 45-1-30.)

35. Alvin Sugar: On a theorem in additive theory of numbers. (Abstract 45-1-65.)

36. H. H. Campaigne: Hypergroup structures. (Abstract 45-1-9.)

37. Nathan Jacobson: Cayley numbers and Lie algebras of type G. (Abstract 45-1-91.)

38. C. B. Allendoerfer: An n-dimensional Gauss-Bonnet theorem. Preliminary report. (Abstract 45-1-2.)

39. S. E. Warschawski: On functions analytic in a half-plane. (Abstract 45-1-73.)

40. W. J. Trjitzinsky: Some general developments in the theory of functions of a complex variable. (Abstract 44-11-475.)

41. Marston Morse and G. A. Hedlund: Symbolic dynamics. II. Sturmian sequences. (Abstract 45-1-46.)

42. C. N. Moore: On a new definition for derivatives of non-integral order. (Abstract 45-1-45.)

43. Dunham Jackson: Linear dependence of polynomials on algebraic curves in space. (Abstract 45-1-26.)

44. S. M. Ulam: On the abstract theory of measure. (Abstract 45-168.)

45. Nelson Dunford and B. J. Pettis: On completely continuous operations in L. (Abstract 45-1-85.)

46. Richard Courant: Conformal mapping of multiply connected domains. (Abstract 45-1-11.)

47. J. L. Kelley: Fixed sets under homeomorphisms. (Abstract 4411-469.)

48. L. W. Cohen: On imbedding a space in a complete space. (Abstract 45-1-10.)

49. G. T. Whyburn: Semi-locally-connected sets. (Abstract 45-1-75.)

50. J. C. Oxtoby: Note on metrically transitive transformations. Preliminary report. (Abstract 45-1-51.)

51. C. C. Torrance: Topologies in which the operation of closure is continuous. (Abstract 45-1-67.)

52. R. G. Lubben: Composition points in abstract spaces. (Abstract 45-1-34.)

53. F. B. Jones: Concerning the boundary of a complementary domain of a continuous curve. (Abstract 44-11-468.)

54. A. D. Wallace: Connected coverings and monotone transformations. (Abstract 45-1-69.)

55. V. W. Adkisson: Closed disconnected sets with unique maps in the plane. (Abstract 44-11-463-t.) 
56. A. A. Albert: New proofs of the main theorems on algebras. (Abstract 45-1-1-t.)

57. E. F. Beckenbach and Maxwell Reade: A characterization of isothermic spherical maps. (Abstract 45-1-76-t.)

58. R. P. Boas (National Research Fellow): The closure of transiations of almost periodic functions. (Abstract 45-1-5-t.)

59. R. P. Boas (National Research Fellow) and Salomon Bochner: On a theorem of M. Riesz for Fourier series. (Abstract 45-1-6-t.)

60. J. W. Calkin: An abstract self-adjoint boundary value problem. (Abstract 45-1-7-t.)

61. Marguerite D. Darkow: Generalized center-circles. (Abstract 44-11-464-t.)

62. Jesse Douglas: The analytic prolongation of a minimal surface over a rectilinear segment of its boundary. (Abstract 44-11-465-t.)

63 . W. W. Flexner: The character group of a relative homology group. (Abstract 45-1-13-t.)

64. H. L. Garabedian: A sufficient condition for Cesàro summability. (Abstract 45-1-86-t.)

65. Saul Gorn: The complete envelope of a non-normal partially ordered set. (Abstract 45-1-17-t.)

66. Saul Gorn: Some theorems on dimensions in partially ordered sets. (Abstract 45-1-16-t.)

67. D. W. Hall (National Research Fellow): Some applications of true secondary elements. (Abstract 45-1-18-t.)

68. O. G. Harrold: On the non-existence of certain continuous transformations defined on an arc. (Abstract 45-1-20-t.)

69. Albert Heins: Some remarks on the solution of partial difference equations. (Abstract 45-1-21-t.)

70. M. H. Heins: Interpolation to functions harmonic and positive or bounded in the unit circle. (Abstract 44-11-466-t.)

71. M. R. Hestenes: Generalized problem of Bolza in the calculus of variations. (Abstract 45-1-22-t.)

72. M. R. Hestenes and W. T. Reid: A note on the Weierstrass condition in the calculus of variations. (Abstract 45-1-23-t.)

73. T. R. Hollcroft: Cuspidal limits for plane curves. (Abstract 451-24-t.)

74. F. B. Jones: Concerning simple linear Moore spaces and simple continuous curves. (Abstract 44-11-467-t.)

75. J. L. Kelley: Concerning a decomposition of compact continua. (Abstract 45-1-29-t.)

76. E. H. Larguier: A matrix theory of $n$-dimensional measurement. (Abstract 45-1-33-t.) 
77. Walter Leighton: New convergence theorems for continued fractions. (Abstract 44-11-470-t.)

78. Norman Levinson: General gap Tauberian theorems. II. (Abstract 44-11-471-t.)

79. Norman Levinson: On functions of minimal exponential type. (Abstract 44-11-472-t.)

80. W. H. McEwen: Note concerning a generalization of Bernstein's theorem. (Abstract 45-1-35-t.)

81. E. J. McShane: Curve-space topologies associated with variational problems. (Abstract 45-1-36-t.)

82. E. J. McShane: On the uniqueness of the solutions of differential equations. (Abstract 45-1-37-t.)

83. Saunders MacLane and O. F. G. Schilling: Infinite number fields with Noether ideal theories. (Abstract 45-1-40-t.)

84. Venable Martin: Monotone transformations of non-compact 2-dimensional manifolds. Preliminary report. (Abstract 45-1-44-t.)

85. Rufus Oldenburger: Minimal numbers. (Abstract 45-1-49-t.)

86. Oystein Ore: $A$ remark on the normal decompositions of groups. (Abstract 45-1-50-t.)

87. W. T. Puckett: A fixed cyclic element theorem. (Abstract 45-155-t.)

88. W. T, Reid: Isoperimetric problems of Bolza in non-parametric form. (Abstract 45-1-56-t.)

89. L. B. Robinson: On an equation solved by a fonctionnelle. (Abstract 45-1-94-t.)

90. A. R. Schweitzer: On the construction of "configurational" sets of ordered dyads in the foundations of geometry. (Abstract 44-11-474-t.)

91. J. A. Shohat: On a differential equation for orthogonal polynomials. (Abstract 45-1-60-t.)

92. A. D. Wallace: On interior transformations. (Abstract 45-170-t.)

93. J. L. Walsh: Maximal convergence of sequences of rational functions. (Abstract 45-1-71-t.)

94. J. L. Walsh: Note on the location of zeros of the derivative of a rationa function whose zeros and poles are symmetric in a circle. (Abstract $45-1-72-t$.)

95. G. T. Whyburn: On irreducibility of transformations. (Abstract 45-1-74-t.)

T. R. Hollcroft, Associate Secretary 